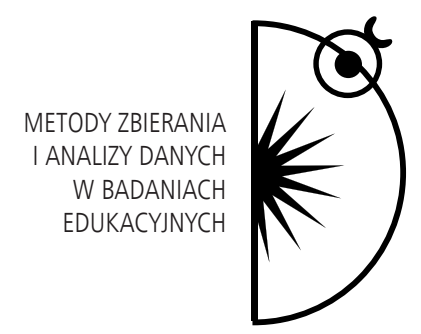

Magdalena Cuprjak

\title{
Tożsamość w kontekście transformacji. Raport z badań
}

DOI: http://dx.doi.org/10.12775/PBE.2013.021

\section{Wprowadzenie}

Anna Brzezińska opublikowała 10 lat temu artykuł pt. Statość i zmiana jako konteksty rozwoju człowieka: o wspólzależności kontekstu, stylu życia i struktu$r y \mathrm{Ja}$, w którym analizuje zmiany w strukturze tożsamości, jakie mogą zachodzić pod wpływem różnych warunków otoczenia. Można by krótko powiedzieć, że określony kontekst społeczny jest determinantą określonego typu tożsamości dorosłego człowieka. Moje obserwacje i rozmowy ze studentami podczas zajęć zaczęły utwierdzać mnie w przekonaniu, że w ciągu ostatnich kilku lat zmieniła się wartość studiów, sposób studiowania oraz sama osoba studentki i studenta. Jaki zatem typ tożsamości posiadają studenci we współczesnym kontekście? Zarówno powyżej zaprezentowany artykuł, jak i udział w codziennym życiu uniwersyteckim były impulsem do przeprowadzenia badań pilotażowych. 


\section{Założenia teoretyczne badań}

Człowiek żyje w dwóch przestrzeniach: czasowej - wymiar horyzontalny i społecznej - wymiar wertykalny (Brzezińska, 2000, s. 18). W przestrzeni czasowej, na kontinuum przeszłości, teraźniejszości i przyszłości, zachodzą zmiany rozwojowe związane z procesem przechodzenia od etapu dziecka do osoby dorosłej. Przestrzeń społeczna natomiast to pełnione przez człowieka role, pozycja zajmowana $\mathrm{w}$ rodzinie i w pracy, podejmowane działania w konkretnym otoczeniu.

Brzezińska (2000, s. 18) pisze, że te dwa wymiary splatają się ze sobą, „tworząc psychologiczny kontekst działania i rozwoju [człowieka - przyp. M. C.]”. Autorka wyróżnia trzy rodzaje tego kontekstu, które tworzą swoiste warunki do działania i stawiają określone wymagania wobec człowieka:

- kontekst konserwatywny - stagnacja społeczna;

- kontekst labilny - transformacja społeczna;

- kontekst stabilny - stabilizacja społeczna.

Zatem stagnacja, stabilizacja czy transformacja? W którym kontekście żyjemy w chwili obecnej? Biorąc pod uwagę treści podawane przez codzienną prasę, serwisy informacyjne oraz Internet, które oscylują wokół takich tematów jak: kryzys, reformy (m.in. szkolnictwa), brak pracy, „walka” o in vitro, związki partnerskie, dyskryminacja kobiet, globalizacja, ochrona środowiska itp., można powiedzieć, że żyjemy w czasach transformacji.

Rozmowy ze studentami, w których wyrażają swoją troskę o przyszłość, a nawet lęk przed kończeniem studiów, również potwierdzają tezę, że transformacja to termin, który jest w stanie objąć wydarzenia i zjawiska, jakie mają miejsce w ostatnich kilku latach w Polsce i na świecie.

Termin „transformacja” jest definiowany jako „przemiana, przeobrażenie, przekształcenie, transfiguracja” (Kopaliński, 2000, s. 511). Nie ma więc znaczenia negatywnego, ale dlatego że wiąże się ze zmianą obecnego status quo, powoduje poczucie niepewności i niemożności przewidzenia swojej przyszłości. Bo czy status magistra daje gwarancję znalezienia dobrej pracy? Studenci podczas dyskusji mówią „nie”, „bo studia straciły na wartości”, „,bo nie ma pracy, nawet po studiach" itp.

$$
* * *
$$

Kontekst społeczny jako determinanta naszych zachowań „oznacza, iż z jednej strony określone warunki życia zachęcają, umożliwiają, a czasami wymusza- 
ją, ale z drugiej utrudniają, zakłócają, a czasami nawet całkowicie uniemożliwiają podejmowanie różnych działań przez jednostkę" (Brzezińska, 2003, s. 14). Można zatem zadać sobie pytanie, w jaki sposób kontekst transformacji społecznej wpływa na struktury psychiczne człowieka, w szczególności na strukturę tożsamości, która zawsze związana jest $\mathrm{z}$ otoczeniem i warunkami społecznymi, w jakich żyje. Człowiek dorosły posiada względną stabilizację w poczuciu własnej tożsamości. Posługując się teorią Marcii (1980; Brzezińska, 2000; Oleszkowicz, 1995; Cuprjak, 2007), można powiedzieć, że w okresie późnej adolescencji człowiek osiąga jeden z czterech statusów: status tożsamości dyfuzyjnej/rozproszonej, status tożsamości lustrzanej/nadanej, status tożsamości odroczonej/moratoryjnej oraz status tożsamości dojrzałej/osiągniętej (cechy poszczególnych statusów prezentuje tabela 1).

Tabela 1. Charakterystyka poszczególnych statusów tożsamości

\begin{tabular}{|c|c|c|c|c|}
\hline & $\begin{array}{l}\text { Dyfuzja } \\
\text { tożsamości }\end{array}$ & $\begin{array}{l}\text { Tożsamość } \\
\text { lustrzana }\end{array}$ & $\begin{array}{l}\text { Tożsamość } \\
\text { odroczona }\end{array}$ & $\begin{array}{c}\text { Tożsamość } \\
\text { dojrzała }\end{array}$ \\
\hline $\begin{array}{l}\text { Planowanie } \\
\text { przyszłości }\end{array}$ & $\begin{array}{l}\text { krótkoterminowe } \\
\text { planowanie } \\
\text { przyszłości; } \\
\text { przyszłość jest } \\
\text { mglista; }\end{array}$ & $\begin{array}{l}\text { dokonywanie } \\
\text { wyborów drogi } \\
\text { życiowej - } \\
\text { w zgodzie } \\
\text { z autorytetem; }\end{array}$ & $\begin{array}{l}\text { przyszłość w fazie } \\
\text { „tworzenia”; }\end{array}$ & $\begin{array}{l}\text { planowanie } \\
\text { przyszłości } \\
\text { w zgodzie } \\
\text { z własnymi } \\
\text { preferencjami; }\end{array}$ \\
\hline $\begin{array}{l}\text { Dokonywanie } \\
\text { wyborów }\end{array}$ & $\begin{array}{l}\text { brak zdolności do } \\
\text { samodzielnych } \\
\text { wyborów; }\end{array}$ & $\begin{array}{l}\text { podejmowanie } \\
\text { określonych } \\
\text { decyzji - w zgodzie } \\
\text { z autorytetem - brak } \\
\text { własnych ustaleń; }\end{array}$ & $\begin{array}{l}\text { widzi alternatywy, } \\
\text { ale nie umie } \\
\text { dokonać wyboru; }\end{array}$ & $\begin{array}{l}\text { dokonuje } \\
\text { samodzielne } \\
\text { wybory; }\end{array}$ \\
\hline Zaangażowanie & $\begin{array}{l}\text { brak zdolności do } \\
\text { angażowania się } \\
\text { w poważniejszą } \\
\text { działalność } \\
\text { życiową; }\end{array}$ & $\begin{array}{l}\text { zaangażowanie jest } \\
\text { wiernym odbiciem } \\
\text { osobowości innych } \\
\text { osób - rodzice, } \\
\text { nauczyciele, idole; } \\
\text { skłonności do } \\
\text { podporządkowania } \\
\text { i konserwatyzmu - } \\
\text { w celu zwiększenia } \\
\text { poczucia } \\
\text { bezpieczeństwa; }\end{array}$ & $\begin{array}{l}\text { niejasne, } \\
\text { przejściowe } \\
\text { zaangażowanie - } \\
\text { walka alternatyw; }\end{array}$ & $\begin{array}{l}\text { zaangażowanie } \\
\text { zgodne } \\
\text { z własnymi } \\
\text { możliwościami; }\end{array}$ \\
\hline
\end{tabular}


Tabela 1 - cd.

\begin{tabular}{|c|c|c|c|c|}
\hline & $\begin{array}{l}\text { Dyfuzja } \\
\text { tożsamości }\end{array}$ & $\begin{array}{l}\text { Tożsamość } \\
\text { lustrzana }\end{array}$ & $\begin{array}{l}\text { Tożsamość } \\
\text { odroczona }\end{array}$ & $\begin{array}{l}\text { Tożsamość } \\
\text { dojrzała }\end{array}$ \\
\hline $\begin{array}{l}\text { Sposób } \\
\text { funkcjonowania } \\
\text { (niezależność } \\
\text { wobec } \\
\text { autorytetów) }\end{array}$ & $\begin{array}{l}\text { kierowanie } \\
\text { się własnymi } \\
\text { korzyściami } \\
\text { i własną } \\
\text { satysfakcją; }\end{array}$ & $\begin{array}{l}\text { odczuwanie silnego } \\
\text { stresu w chwili, } \\
\text { gdy nie funkcjonują } \\
\text { kryteria wartości } \\
\text { autorytetu; }\end{array}$ & $\begin{array}{l}\text { chęć uzyskania } \\
\text { kompromisu między } \\
\text { presją społeczną } \\
\text { a własnymi } \\
\text { preferencjami; } \\
\text { eksperymentowanie } \\
\text { identyfikacyjne } \\
\text { w celu weryfikacji } \\
\text { identyfikacji } \\
\text { dziecięcych; } \\
\text { dyskomfort } \\
\text { z powodu } \\
\text { niejasnego } \\
\text { kierunku własnych } \\
\text { poszukiwań; }\end{array}$ & $\begin{array}{l}\text { poznanie własnych } \\
\text { preferencji, } \\
\text { w zgodzie } \\
\text { z którymi są } \\
\text { podejmowane } \\
\text { działania - } \\
\text { nie ulegają } \\
\text { nadmiernym } \\
\text { wpływom i nie } \\
\text { są skłonne do } \\
\text { załamywań } \\
\text { pod wpływem } \\
\text { trudności; }\end{array}$ \\
\hline $\begin{array}{l}\text { Kryzys } \\
\text { tożsamości }\end{array}$ & $\begin{array}{l}\text { nie występował } \\
\text { jeszcze kryzys } \\
\text { tożsamości; }\end{array}$ & $\begin{array}{l}\text { nie występował } \\
\text { jeszcze kryzys } \\
\text { tożsamości; }\end{array}$ & $\begin{array}{l}\text { jednostka przeżywa } \\
\text { kryzys tożsamości; }\end{array}$ & $\begin{array}{l}\text { pozytywne } \\
\text { rozwiązanie } \\
\text { kryzysu } \\
\text { tożsamości; }\end{array}$ \\
\hline
\end{tabular}

Źródło: Cuprjak, 2010.

Ze względu na związek, jaki istnieje pomiędzy warunkami społecznymi a konstrukcją tożsamości, należy spodziewać się zmian w strukturze tożsamości, w zależności od rodzaju kontekstu. W warunkach transformacji człowiek będzie skupiony na teraźniejszości ze względu na trudność w przewidywaniu przyszłości. Będzie szukał optymalnych warunków do zaspokojenia swoich potrzeb, na zasadzie wykorzystywania tego, co dzieje się „tu i teraz”. Dominującym typem tożsamości może być status tożsamości odroczonej, ponieważ „na skutek gwałtownego poszerzenia się pola eksploracji” zarówno osoby o tożsamości dyfuzyjnej, jak i osiągniętej będą wykazywały tendencję do moratorium. Osoba o tożsamości odroczonej albo w niej pozostanie, albo przejdzie w stan dyfuzji, natomiast osoba o tożsamości lustrzanej prawdopodobnie pozostanie w tym stanie lub wykorzysta pojawiające się szanse i przejdzie w status tożsamości osiągniętej (rys. 1.; Brzezińska, 2003, s. 19 i n.). 
Rysunek 1. Zmiany statusu tożsamości w warunkach transformacji

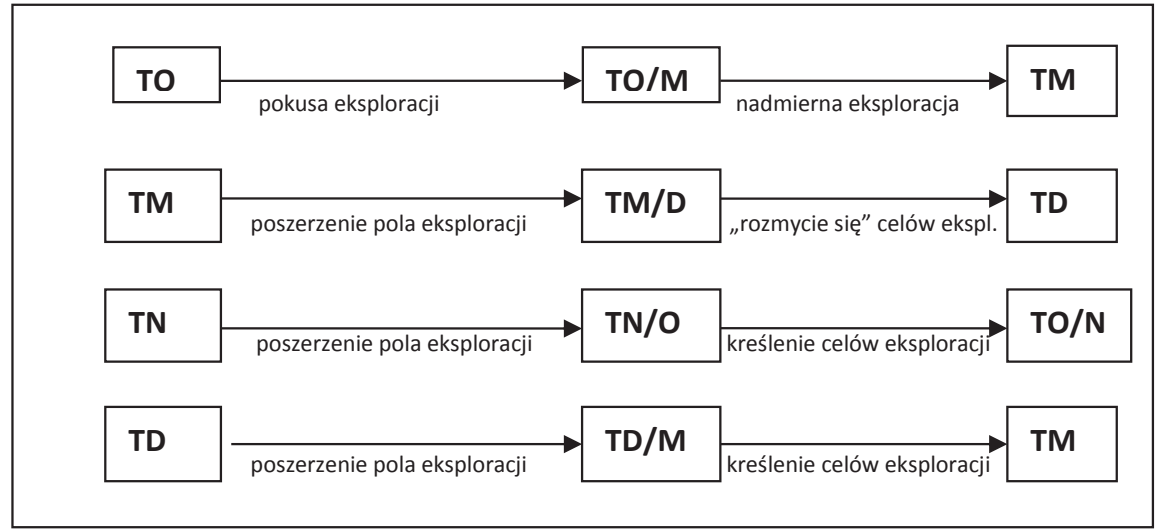

Źródło: Brzezińska, 2003, s. 20.

\section{Założenia metodologiczne badań}

Powyższe rozważania pozwoliły na sformułowanie głównego pytania badawczego: „Jaki status tożsamości dominuje wśród studentek i studentów w obecnym czasie transformacji?”. Czy jest to tożsamość odroczona lub dyfuzyjna, jak wskazuje na to Brzezińska (2003, s. 20)? Poza tym badania mają na celu sprawdzenie, czy kierunek studiów - jako również swoisty rodzaj kontekstu społecznego - ma znaczenie dla struktury tożsamości. Dla porównania wybrałam dwa skrajne kierunki: ścisły - fizyka, oraz społeczny - pedagogika.

Szczegółowe pytania badawcze są następujące:

Jaki jest rozkład wyników badanych studentek i studentów w obszarze poszczególnych statusów tożsamości, mierzonych Testem Statusów Tożsamości?

Czy istnieje związek pomiędzy osiąganym statusem tożsamości a studiowaniem na kierunku fizyka i pedagogika?

Badanymi zmiennymi są:

- zmienna ustalona: kierunek studiów - fizyka, pedagogika,

- zmienna losowa: status tożsamości - dyfuzyjnej, lustrzanej, odroczonej, dojrzałej.

Podjęte badania już na etapie założeń ujawniły, że trudno będzie udzielić odpowiedzi na pytanie o związek pomiędzy statusem tożsamości a kierunkiem studiów. Trudność wynika ze struktury płci badanych grup. Istnieje bowiem ścisły związek pomiędzy płcią a kierunkiem studiów. Pedagogikę studiują głównie kobiety, a fizykę mężczyźni. A zatem płeć jest zmienną, która zakłóca 
rozpatrywany związek. Odpowiedź na stawiane pytanie może być naznaczona błędem.

Badania były prowadzone od stycznia do marca 2013 r. Zostało nimi objętych 178 osób, studentów dwóch kierunków studiów, jednego o charakterze „ścisłym” - fizyki, a drugiego o charakterze „społecznym” - pedagogiki. Struktura badanych grup była następująca:

- 120 osób to studentki i studenci pedagogiki; 58 osób to studenci i studentki fizyki;

- średnia wieku wynosi 20,35; min. 19, max. 24 lata;

- na pedagogice $98,3 \%$ to kobiety; na fizyce $87,9 \%$ to mężczyźni;

- wszyscy są studentami studiów stacjonarnych pierwszego stopnia;

Dobór badanych do próbki badawczej był celowy, a podstawowym kryterium było uczęszczanie na studia na wybranych kierunkach. Różnica w liczebności obu grup w ogóle, a także liczebności kobiet i mężczyzn na obu kierunkach, jest naturalna. Na studiach pedagogicznych studiuje kilka razy więcej osób niż na studiach fizycznych, a ponadto pedagogikę studiuje większość kobiet, a fizykę większość mężczyzn.

Badania miały charakter quasi-eksperymentalny (Rubacha, 2009). Metodą zbierania danych było testowanie przy użyciu testu do badania statusu tożsamości TST mojego autorstwa. Test jest oparty na technice skali szacunkowej z wymuszonym wyborem Cosgrove'a (Brzeziński, 1978), w której pomiar o charakterze ipsatywnym odbywa się przez rangowanie odpowiedzi w ramach każdej pozycji testu (w tym przypadku są cztery odpowiedzi, adekwatne dla czterech statusów tożsamości). Z uzyskanych wyników cząstkowych otrzymujemy profil psychometryczny, dzięki czemu możemy odczytać, który ze statusów jest ważniejszy w stosunku do pozostałych.

Przeprowadzone badania umożliwiły również aktualizację norm testu dla grupy osób w okresie wczesnej dorosłości (pierwsza normalizacja była wykonana w 2006 r.; Cuprjak, 2007). Wyniki normalizacji prezentuje tabela 2.

Tabela 2. Normalizacja TST

\begin{tabular}{|l|c|c|c|c|}
\hline \multirow{2}{*}{} & \multicolumn{4}{|c|}{ Status tożsamości } \\
\cline { 2 - 5 } & dyfuzyjnej & lustrzanej & odroczonej & dojrzałej \\
\hline niski (1) & $10-14$ & $10-21$ & $10-26$ & $10-28$ \\
\hline przeciętny (2) & $15-18$ & $22-24$ & $27-29$ & $29-33$ \\
\hline wysoki (3) & $19-40$ & $25-40$ & $30-40$ & $34-40$ \\
\hline
\end{tabular}

Źródło: badania własne. 
Uzyskane wyniki zostały zatem znormalizowane, a więc sprowadzone do postaci dyskretnej o wartościach: 1 - poziom niski, 2 - poziom przeciętny, 3 poziom wysoki. Do analiz zgromadzonych danych użyto tabel krzyżowych oraz współczynnika kontyngencji, na podstawie którego możemy stwierdzić, czy zachodzi związek pomiędzy zmiennymi nominalnymi i jaka jest jego siła (Rubacha, 2009; Rycielski, Brzezicka, 2007, s. 181).

\section{Analiza i interpretacja wyników badań}

Analizując rozkład procentowy w obszarze poszczególnych statusów tożsamości, w celu odpowiedzi na pytanie: jaki jest rozkład wyników badanych studentek i studentów w obszarze poszczególnych statusów tożsamości mierzonych Testem Statusów Tożsamości, można zauważyć, że najwyższe wartości w zakresie wyników wysokich uzyskał status tożsamości lustrzanej 38,8\%. Wykres dla tego statusu jest wyraźnie skośny ujemnie, co świadczy o tendencji do uzyskiwania wyników wysokich. Na drugim miejscu jest status tożsamości odroczonej $36,8 \%$, na trzecim dojrzałej $31,4 \%$, a na czwartym dyfuzyjnej $30,2 \%$.

Tabela 3. Rozkład procentowy wyników w obszarze poszczególnych statusów tożsamości

\begin{tabular}{|l|c|c|c|c|}
\hline & dyfuzyjna & lustrzana & odroczona & dojrzała \\
\hline niskie & 25,2 & 28,1 & 36,4 & 28,5 \\
\hline przeciętne & 44,6 & 33,1 & 26,9 & 40,1 \\
\hline wysokie & 30,2 & 38,8 & 36,8 & 31,4 \\
\hline
\end{tabular}

Źródło: opracowanie własne.

Można więc powiedzieć, że ogólnie badana młodzież wykazuje tendencje do prezentowania statusu tożsamości lustrzanej. Zatem czas transformacji, tzw. poszerzanie się pola eksploracji jest albo niezauważalne, albo powoduje u studiującej młodzieży lęk, który jeszcze bardziej zamyka ją na dziejące się zmiany i powoduje ucieczkę do znanego i „oswojonego już świata”. 
Rysunek 2. Rozkład procentowy wyników w obszarze poszczególnych statusów tożsamości

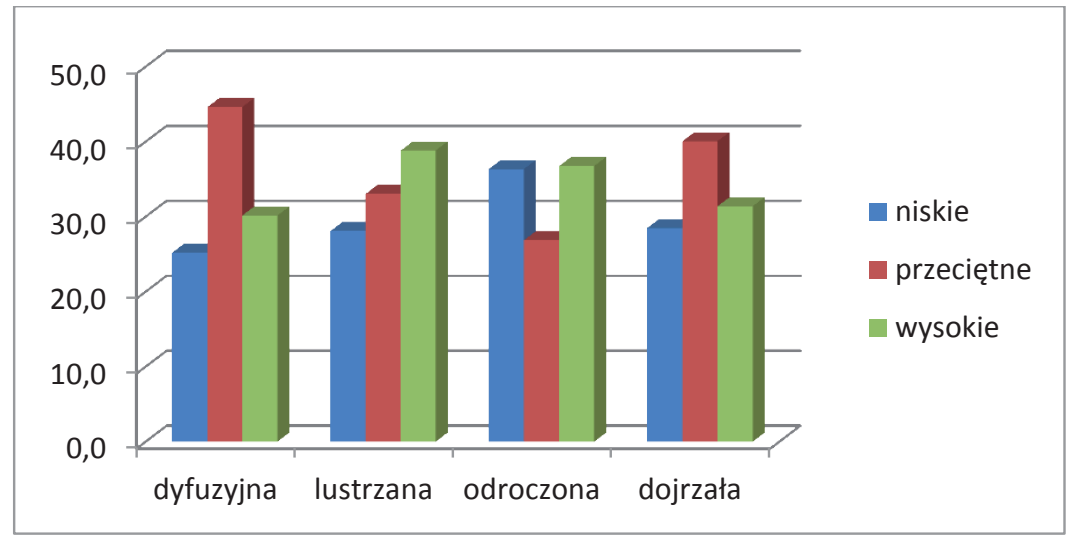

Źródło: opracowanie własne.

Tożsamość lustrzana jest najbardziej adaptacyjną tożsamością wśród pozostałych, jest również najbardziej charakterystyczna dla kontekstu stagnacji. Człowiek podąża wyznaczonym szlakiem, angażując się w wybrane obszary, ale bez podejmowania eksploracji. Zaangażowanie jest wynikiem wpływu znaczących dla niego osób, a nie rozpatrywania różnorodnych alternatyw. Stwierdzenie „robię tak, bo tak robią inni” jest niejako wizytówką osoby o tym statusie tożsamości. Tym bardziej zaskakujący jest fakt dominacji tego statusu nad pozostałymi. Czy samo studiowanie jest pewnego rodzaju kontekstem stagnacji? Te wątpliwości wymagają kolejnych badań i wnikliwych analiz.

$$
\text { * * * }
$$

Kolejne analizy ujawniły związek pomiędzy kierunkiem studiów a statusem tożsamości badanej młodzieży studenckiej.

W zakresie tożsamości dyfuzyjnej studenci pedagogiki i fizyki uzyskali różne wyniki. Jak widać w tabeli 4 oraz na rysunku 3, najwyższe wartości procentowe na pedagogice uzyskano w zakresie wyników przeciętnych, natomiast na fizyce w zakresie wyników wysokich. Można również zauważyć, że wykres dla wyników studentów fizyki jest wyraźnie skośny ujemnie, co potwierdza tendencję do wysokich wartości. 
Tabela 4. Rozkład wyników w obszarze statusu tożsamości dyfuzyjnej

\begin{tabular}{|l|c|c|c|c|}
\hline & \multicolumn{2}{|c|}{ pedagogika } & \multicolumn{2}{c|}{ fizyka } \\
\hline & N & $\%$ & N & $\%$ \\
\hline niski & 39 & 32,5 & 8 & 13,8 \\
\hline przeciętny & 55 & 45,8 & 20 & 34,5 \\
\hline wysoki & 26 & 21,7 & 30 & 51,7 \\
\hline ogółem & 120 & 100,0 & 58 & 100,0 \\
\hline
\end{tabular}

Źródło: opracowanie własne.

Rysunek 3. Rozkład wyników w obszarze statusu tożsamości dyfuzyjnej

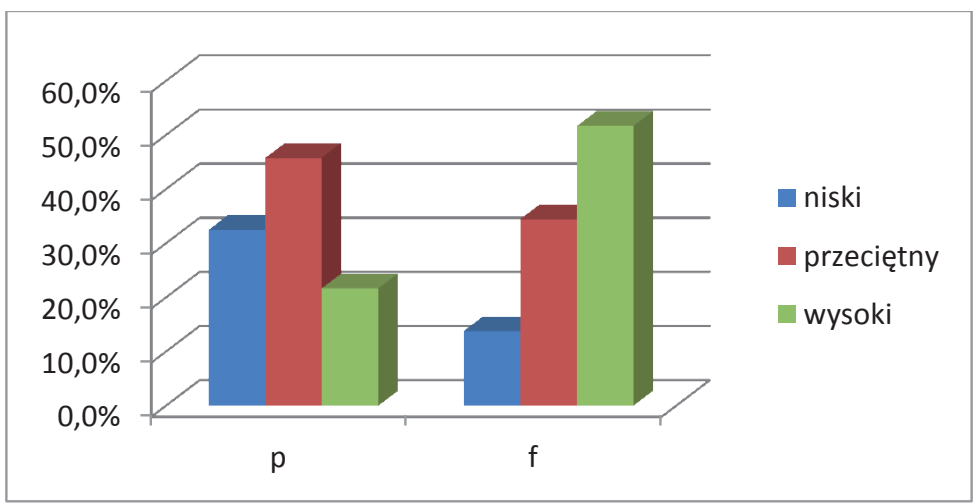

Źródło: opracowanie własne.

Zastosowany test do analizy związku pomiędzy zmiennymi nominalnymi wykazał powiązanie między kierunkiem studiów a statusem tożsamości: współczynnik kontyngencji równa się 0,$3 ; \mathrm{p}<0,01$. Na podstawie wyniku testu oraz danych z tabeli krzyżowej można powiedzieć, że studenci fizyki mają większą tendencję do prezentowania statusu tożsamości dyfuzyjnej.

W zakresie kolejnego statusu tożsamości można zaobserwować, że studenci pedagogiki najwyższe rezultaty uzyskali w obszarze wyników wysokich, natomiast studenci fizyki - przeciętnych, a zatem studenci pedagogiki mają większą tendencję do prezentowania statusu tożsamości lustrzanej niż studenci fizyki. 
Potwierdza to również skośność rozkładu dla pedagogiki, który jest skośny ujemnie, wskazując na tendencję w kierunku wyników wysokich. Współczynnik kontyngencji nie wykazał jednak, aby związek pomiędzy kierunkiem studiów a wynikami w zakresie tożsamości lustrzanej był istotny statystycznie $(\mathrm{p}>0,05)$.

Tabela 5. Rozkład wyników w obszarze statusu tożsamości lustrzanej

\begin{tabular}{|l|c|c|c|c|}
\hline & \multicolumn{2}{|c|}{ pedagogika } & \multicolumn{2}{c|}{ fizyka } \\
\hline & N & $\%$ & N & $\%$ \\
\hline niski & 33 & 27,5 & 15 & 25,9 \\
\hline przeciętny & 38 & 31,7 & 24 & 41,4 \\
\hline wysoki & 49 & 40,8 & 19 & 32,8 \\
\hline ogółem & 120 & 100,0 & 58 & 100,0 \\
\hline
\end{tabular}

Źródło: opracowanie własne.

Rysunek 4. Rozkład wyników w obszarze statusu tożsamości lustrzanej

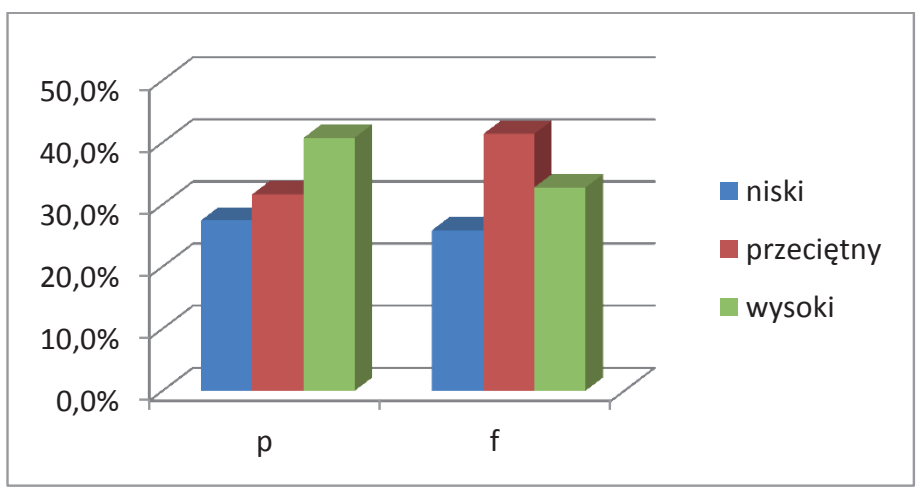

Źródło: opracowanie własne.

Wartości uzyskane w obszarze kolejnego statusu tożsamości wskazują, że studenci pedagogiki mają większe, niż studenci fizyki, tendencje do prezentowania tożsamości odroczonej. Najwyższe wyniki uzyskali bowiem w zakresie wyników wysokich, a studenci fizyki - w zakresie wyników niskich. Prezentuje to 
również wykres, który dla studentów fizyki jest wyraźnie skośny dodatnio, a dla studentów pedagogiki ujemnie.

Tabela 6. Rozkład wyników w obszarze statusu tożsamości odroczonej

\begin{tabular}{|l|c|c|c|c|}
\hline & \multicolumn{2}{|c|}{ pedagogika } & \multicolumn{2}{c|}{ fizyka } \\
\hline & $\mathbf{N}$ & $\%$ & $\mathbf{N}$ & $\%$ \\
\hline niski & 32 & 26,7 & 32 & 55,2 \\
\hline przeciętny & 32 & 26,7 & 13 & 22,4 \\
\hline wysoki & 56 & 46,7 & 13 & 22,4 \\
\hline ogółem & 120 & 100,0 & 58 & 100,0 \\
\hline
\end{tabular}

Źródło: opracowanie własne.

Rysunek 5. Rozkład wyników w obszarze statusu tożsamości odroczonej

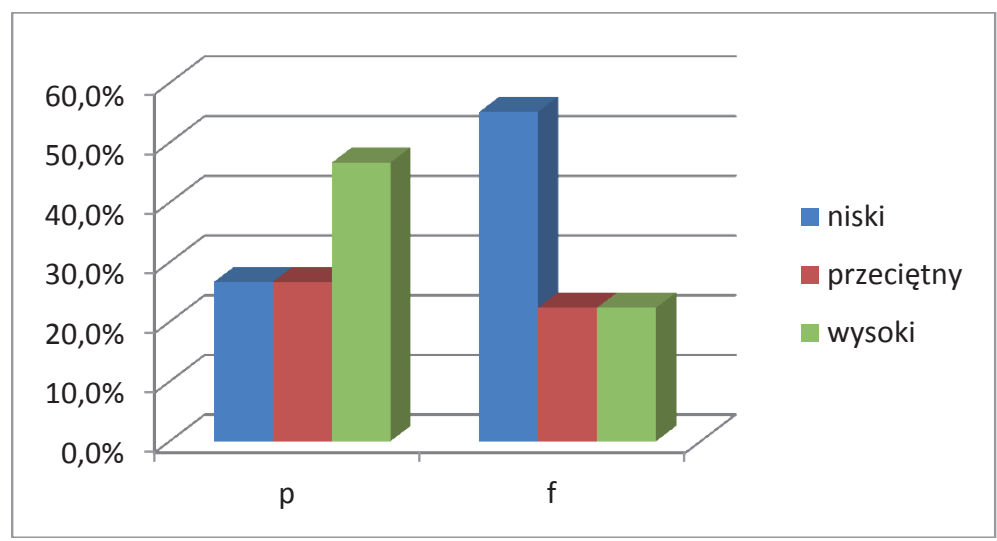

Źródło: opracowanie własne.

Zastosowany test wykazał, że istnieje związek istotny statystycznie pomiędzy wynikami uzyskanymi w obszarze analizowanego statusu tożsamości a kierunkiem studiów: współczynnik kontyngencji wynosi 0,$28 ; p<0,01$. Biorąc pod uwagę zarówno wynik testu, jak i wyniki w tabeli krzyżowej, można powiedzieć, że studenci pedagogiki w większym stopniu wykazują tendencję do tożsamości odroczonej niż studenci fizyki. 
W zakresie tożsamości dojrzałej w obu badanych grupach najwyższe częstości uzyskano w wynikach przeciętnych. Wśród wyników studentów pedagogiki można zaobserwować bardziej wyrównany rozkład na trzech poziomach, natomiast wśród wyników studentów fizyki wyraźnie dominują wartości przeciętne.

Analizy nie wykazały, aby związek pomiędzy badanymi zmiennymi był istotny statystycznie, można więc powiedzieć, że studenci w podobny sposób prezentują status tożsamości dojrzałej.

Tabela 7. Rozkład wyników w obszarze statusu tożsamości dojrzałej

\begin{tabular}{|l|c|c|c|c|}
\hline & \multicolumn{2}{|c|}{ pedagogika } & \multicolumn{2}{c|}{ fizyka } \\
\hline & N & $\%$ & N & $\%$ \\
\hline niski & 31 & 25,8 & 15 & 25,9 \\
\hline przeciętny & 50 & 41,7 & 27 & 46,6 \\
\hline wysoki & 39 & 32,5 & 16 & 27,6 \\
\hline ogółem & 120 & 100,0 & 58 & 100,0 \\
\hline
\end{tabular}

Źródło: opracowanie własne.

Rysunek 6. Rozkład wyników w obszarze statusu tożsamości dojrzałej

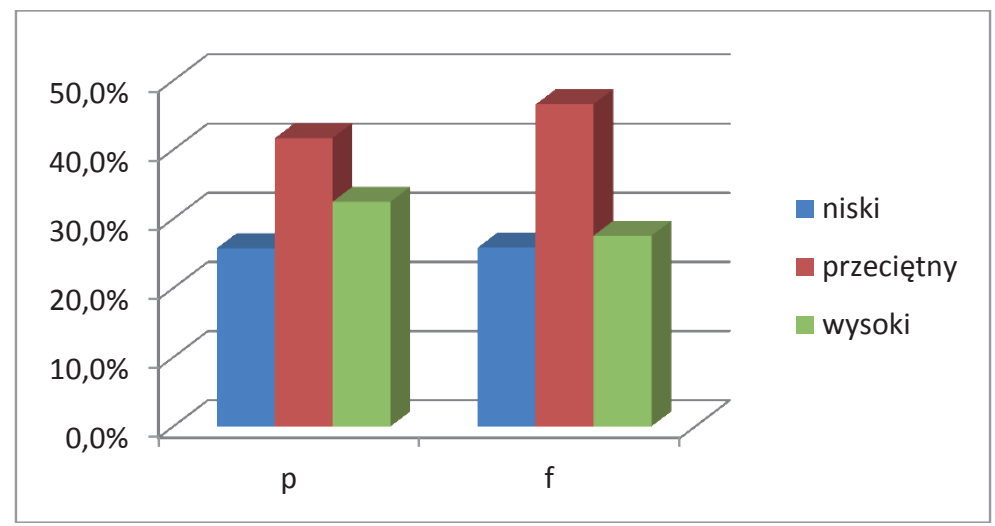

Źródło: opracowanie własne. 
Uzyskane rezultaty $\mathrm{w}$ postaci dominacji statusu tożsamości lustrzanej w ogólnej próbce badawczej nie potwierdzają założeń badań, korespondujących z rozważaniami teoretycznymi Brzezińskiej (2003, s. 20). Jednakże badania nie pokazują zmiany tożsamości w warunkach transformacji, a jedynie jej stan w chwili wypełniania testu. Aby w pełni odnieść otrzymane wyniki do zastosowanej teorii, należałoby wykonać badania podłużne, w przynajmniej kilkuletniej perspektywie czasowej.

Na drugim miejscu pojawia się status tożsamości odroczonej, a więc nadal jest ważniejszy o dwóch pozostałych - statusu tożsamości dyfuzyjnej i dojrzalej. Tożsamość odroczona wydaje się naturalna w okresie studiowania. Studenci mają tendencję do odsuwania zaangażowania w ważne sprawy życiowe, ponieważ są w trakcie eksploracji alternatyw. Być może jednak czas niepewności o własną przyszłość powoduje z jednej strony ucieczkę w konserwatyzm działania (tożsamość lustrzana), a z drugiej jednak szukanie nowych rozwiązań (tożsamość odroczona).

Wyniki porównawcze badanych grup pokazują istotne różnice w obszarze statusów tożsamości dyfuzyjnej i odroczonej. Te dwa statusy określane są jako niestabilne, m.in. z powodu braku umiejętności dokonywania wyborów i trudności w zaangażowaniu się w poważne sprawy życiowe (Marcia, 1980; Cuprjak, 2007). Poza tym „żaden z nich nie charakteryzuje się stabilną tożsamością, mimo że moratorium ku takiej zmierza" (Marcia, 1980, s. 174) Różnica między nimi polega głównie na tym, że człowiek o tożsamości dyfuzyjnej nie widzi potrzeby, aby w coś się angażować, a człowiek o tożsamości odroczonej widzi zbyt wiele alternatyw, aby na jakąś się zdecydować. Porównując wyniki każdej z grup osobno, widać, że studenci pedagogiki najwyższe rezultaty uzyskali w obszarze statusu tożsamości odroczonej, a studenci fizyki - dyfuzyjnej.

Wracając do rozmów ze studentami pedagogiki, mogłam się podczas nich dowiedzieć, że studenci kierunków ścisłych mają potoczną opinię osób zdecydowanych, co w życiu chcą robić, a o studentach kierunków humanistyczno-społecznych mówi się, że zależy im na ogólnym wykształceniu. Według tak sformułowanych założeń studenci fizyki powinni wykazywać tendencję do tożsamości dojrzałej lub lustrzanej, a studenci pedagogiki - odroczonej lub dyfuzyjnej. Studenci, a w znakomitej większości studentki pedagogiki, rzeczywiście wykazują moratorium w obszarze tożsamości. Odraczają zaangażowanie, ich przyszłość jest w fazie tworzenia i mają szansę na przejście na poziom tożsamości dojrzałej. Zaskakujące są jednak wyniki w zakresie tożsamości dyfuzyjnej 
na fizyce. Dlaczego studenci (głównie mężczyźni) nie mają potrzeby zaangażowania, a ich przyszłość jest tak mglista, że trudno jest podjąć próbę planowania?

Interpretacja różnic między grupami jest trudna z powodu zmiennej zakłócającej - płci. Jeśli przyjęlibyśmy, że badamy różnice między kobietami a mężczyznami, to Miluska w swoich badaniach wykazała, że generalnie większość dorosłych osób charakteryzuje się statusem tożsamości osiągniętej, a różnice płciowe zarysowują się w hierarchii pozostałych statusów. Mianowicie w grupie mężczyzn na drugim miejscu pojawia się status tożsamości dyfuzyjnej, a w grupie kobiet - odroczonej (Miluska, 1996, s. 228). Można więc wnioskować, że kobiety wykazują większą aktywność w procesie eksploracji różnych dziedzin wartych w ich poczuciu zaangażowania, a tym samym, ich wypracowana tożsamość może mieć bardziej stabilne podstawy. Jest to propozycja warta $\mathrm{w}$ przyszłości rozpatrzenia.

Może to również być związane z nieadekwatnością teorii Marcii do współczesnych warunków, a tym samym zastosowanego testu. Możliwe jest, że nie możemy już stosować tzw. czystych i jednoznacznych stanów tożsamości. Tożsamość człowieka jest tak zróżnicowana jak współczesność, w jakiej żyje, i w każdym z nas jest pierwiastek każdego ze statusów, który wychodzi na pierwszy plan w zależności od potrzeby.

\section{Zakończenie}

Prezentowane rezultaty badań mają charakter pilotażowy. Pokazują pewne ścieżki warte głębszych analiz, trudne do zbadania obszary, ale również pewne ważne fakty. Bardzo ważną informacją jest to, że wyniki badanych studentów wskazują na ich niedojrzałość tożsamościową. Być może jest to właśnie efekt kontekstu transformacji - nieustanny brak dojrzałości? Można by przywołać tu propozycje Melosika o istnieniu tożsamości ponowoczesnych, takich jak: tożsamość globalna przezroczysta, tożsamość globalna każda, tożsamość typu supermarket, tożsamość upozorowana oraz tzw. horyzontalna (Melosik, 2010). Która dominuje? Każda i żadna, ponieważ bardzo prawdopodobne jest ich wymieszanie i tworzenie kolejnej jakości. Czy możliwe jest zatem zbadanie współczesnego typu tożsamości? Mam nadzieję, że tak. 


\section{Bibliografia}

Brzezińska A. (2000) Społeczna psychologia rozwoju, Wydawnictwo Naukowe „Scholar”, Warszawa.

Brzezińska A. (2003), Stałość i zmiana jako konteksty rozwoju człowieka: o wspótzależności kontekstu, stylu życia i struktury Ja, w: Derbis R. (red.), Niepokoje i nadzieje współczesnego człowieka. Człowiek w sytuacji przełomu, Wyższa Szkoła Pedagogiczna w Częstochowie, Częstochowa, s. 14-30.

Brzeziński J. (1978), Elementy metodologii badań psychologicznych, Wydawnictwo Naukowe PWN, Warszawa.

Cuprjak M. (2007), Tożsamość a rola nauczyciela w okresie wczesnej dorostości, Uniwersytet Mikołaja Kopernika, Toruń.

Marcia J. (1980), Identity in adolescence, w: Adelson J. (ed.), Handbook of adolescent psychology, John Wiley, New York.

Melosik Z., Szkudlarek T. (2010), Kultura, tożsamość i edukacja. Migotanie znaczeń, http:// www.pedgds.univ.gda.pl/melosik.szkudlarek.pdf, s. 48-54 (dostęp: 6.02.2010).

Miluska J. (1996), Tożsamość kobiet i mężczyzn w cyklu życia, Wydawnictwo Naukowe UAM, Poznań.

Rubacha K. (2008), Metodologia badań nad edukacja, Wydawnictwa Akademickie i Profesjonalne, Warszawa.

Rycielski P., Brzezicka A. (2007), Wnioskowanie statystyczne na danych jakościowych: testy oparte na rozktadzie chi-kwadrat, w: Bedyńska S., Brzezicka A. (red.), Statystyczny drogowskaz. Praktyczny poradnik analizy danych w naukach społecznych na przykładach z psychologii, Wydawnictwo SWPS Academica, Warszawa.

\section{The identity in transformation context. Research report}

\section{Summary}

The article presents results of studies concerning the relationship between identity status and specific field of study. Researches, have been conducted on students of pedagogy and physics at Nicolai Copernicus University in Torun. The identity is also considered in transformation conditions, which the author think, are the current social context of modern man.

Keywords: identity status, social context, transformation context. 